\title{
Faktor-Faktor yang Mempengaruhi Financial Distress
}

\author{
Endriana Winda Wulandari*, Jaeni \\ Fakultas Ekonomika dan Bisnis, Universitas Stikubank (UNISBANK) Semarang \\ Jl. Kendeng V Bendan Ngisor, Semarang, Indonesia \\ *Correspondence e-mail: ewindawulandari@gmail.com
}

\begin{abstract}
Abstrak. Penelitian yang dilakukan memiliki tujuan guna menganalisis adanya pengaruh dari arus kas operasi, leverage, likuiditas, operating capacity, profitabilitas dan sales growth terhadap financial distress perusahaan Property dan Real Estate Bursa Efek Indonesia (BEI) 2015-2019. Penelitian ini termasuk jenis penelitian kuantitatif dengan menggunakan data sekunder. Sampel pada penelitian diperoleh sebanyak 26 perusahaan, pada halnya metode yang digunakan ialah purposive sampling yang merupakan suatu metode pengambilan sampel dengan melakukan penetapan pada kriteria-kriteria yang telah ditentukan. Metode analisis data menggunakan regresi linier berganda. Hasil penelitian dari uji F menunjukkan variabel arus kas operasi, leverage, likuiditas, operating capacity, profitabilitas, dan sales growth berpengaruh secara bersamaan terhadap financial distress. Namun dalam pengujian hipotesis (uji-t) variabel arus kas operasi, operating capacity, profitabilitas dan sales growth tidak berpengaruh terhadap financial distress, sedangkan variabel leverage dan likuiditas berpengaruh signifikan dan negatif terhadap financial distress.
\end{abstract}

Kata kunci: Arus Kas Operasi; Financial Distress; Leverage; Likuiditas; Profitabilitas

Abstract. This study aims to analyze the influence of operating cash flow, leverage, liquidity, operating capacity, profitability and sales growth on the financial distress of Property and Real Estate companies on the Indonesia Stock Exchange (IDX) 2015-2019. This research is a type of quantitative research using secondary data. The sample in this study obtained as many as 26 companies, in the case of the method used is purposive sampling which is a sampling method by determining the criteria that have been determined. The data analysis method used multiple linear regression. The results of the F test show that operating cash flow, leverage, liquidity, operating capacity, profitability, and sales growth variables simultaneously affect financial distress. However, in testing the hypothesis (t-test) the operating cash flow, operating capacity, profitability and sales growth variables have no effect on financial distress, while the leverage and liquidity variables have a significant and negative effect on financial distress.

Keywords: Financial Distress; Leverage; Liquidity; Operating Cash Flow; Profitability

\section{PENDAHULUAN}

Sektor perusahaan Property dan Real Eestate ialah indikator terpenting dalam melihat perkembangan ekonomi suatu negara. Industri property ialah sektor pertama untuk melihat sejauh mana perekonomian negara dan memberikan sinyal jatuh bangunnya perekonomian dari sebuah negara. Keadaan ekonomi suatu negara sangat mempengaruhi kemungkinan adanya mengalami kesulitan keuangan salah satunya sinyal bahwa perusahaan mengalami kesulitan keuangan adalah penurunan keuangan kondisi sebelum perusahaan dinyatakan bangkrut. Salah satu terjadinya kesulitan keuangan adalah peningkatan hutang yang akan meningkatkan biaya antar bunga. Jika manajemen dalam mengelola perusahaan tidak baik, maka dapat dikatakan tidak mampu dalam membayar hutang dan biaya bunga. Maka, setiap perusahaan diharapkan untuk meningkatkan kinerjanya agar terhindar dari masalah kesulitan keuangan (Saputri \& Asrori, 2019).

Financial Distress merupakan langkah dimana keadaan finansial yang timbul sebelum mengalami keterpurukan. Kesulitan keuangan dapat terjadi akibat perusahaan tidak dapat menjaga dan mengatur kemampuan keuangan dengan baik dan menyebabkan perusahaan mengalami kerugian. Dalam perkembangan bidang sektor perusahaan Property dan Real Estate di tahun 2016 hingga tahun 2017 terdapat permasalahan sebab penjualan perumahan maupun ruko-ruko yang dibangun perusahaan banyak yang belum laku terjual. Dengan demikian, bangunan perumahan perusahaan yang belum laku terjual tersebut dapat menyebabkan penurunan laba pada perusahaanya dan mengalami potensi adanya financial distress pada perusahaan.

Menurut (Restianti \& Agustina, 2018), salah satu indikator terpenting dalam menganalisis laporan keuangan adalah untuk melihat terjadi atau tidaknya potensi kebangkrutan karena adanya kesulitan keuangan dalam perusahaan. Situasi tersebut memperlihatkan betapa pentingnya memahami alasan dibalik runtuhnya perusahaan sebelum perusahaan tersebut dikatakan bangkrutan dan berpotensi mengalami financial distress. Terdapat faktor eksternal dan internal penyebab terjadinya kebangkrutan. Dari faktor eksternal sendiri adalah kesulitan bahan baku karena supplier tidak menyuplai bahan baku untuk diproduksi. Sedangkan faktor internal dilihat dari finansialnya, seperti terlalu banyak berhutang, pengelolaan dana yang salah dan juga kurangnya kapitalisasi dana (Carolina dan Pratama, 2017).

Dalam mengurangi resiko kebangkrutan, faktor utama yang perlu diperhatikan adalah dengan cara menganalisis sebab terjadinya kebangkrutan pada suatu 
perusahaan yang telah dinyatakan bahwa perusahaan tersebut berpotensi mengarah adanya financial distress dan juga faktor-faktor yang berpengaruh terhadap financial distress yang akan memberikan banyak keuntungan terutama bagi pihak kreditur dan investor dalam memprediksi kebangkrutan. Banyak faktor yang mempengaruhi kesulitan keuangan diantaranya arus kas operasi, leverage, likuiditas, operating capacity, profitabilitas dan sales growth. Pada penelitian ini berperan dalam menguji beberapa faktor-faktor yang dapat memicu kesulitan keuangan dalam perusahaan Property and Real Estate yang terdaftar di Bursa Efek Indonesia (BEI).

\section{Pengaruh Arus Kas Operasi Terhadap Financial Distress}

Arus Kas Operasi berperan dalam pemberian informasi yang relevan mengenai arus kas masuk dan arus kas keluar pada laporan keuangan terdiri dari kegiatan operasi, pembiayan dan investasi dapat (Kanzha \& Muslih, 2020). Berdasarkan hubungan teori signal dengan arus kas operasi menunjukkan bahwa khususnya bagi pengguna laporan keuangan yaitu pihak kreditur guna dapat memberikan sinyal positif ataupun negatif. Dalam hal ini, jumlah arus kas operasi yang menunjukkan baik dapat memperlihatkan bahwa perusahaan dapat memperoleh arus kas yang baik dalam melunasi hutang perusahaan, mempertahankan kemampuan operasi entitas, dan membayarkan dividennya, maka dari itu dapat memberikan sinyal positif bagi kreditur yang dapat memperlihatkan bahwa perusahaan sedang tidak berpotensi mengalami kondisi financial distress ditinjau dari segi kinerja keuangannya.

Hasil penelitian dari Ramadhani (2019), Aisyah dan Zultilisna (2017) dan Ayuningtyas (2019) menunjukan bahwa arus kas operasi berpengaruh positif dan signifikan terhadap financial distress. Namun berbeda dengan penelitian Julius (2017) dan Finishtya (2020) membuktikan bahwa arus kas operasi berpengaruh negatif dan signifikan terhadap financial distress.

\section{Pengaruh Leverage Terhadap Financial Distress}

Leverage ialah sebuah rasio yang memperlihatkan seberapa banyak perusahaan mampu dalam memenuhi total kewajiban dan rasio ini menunjukan berapa banyak aset yang didanai oleh utang (Moch, et.all., 2019). Semakin tinggi aktivitas perusahaan dianggarai oleh hutang, maka dapat semakin tinggi juga potensi adanya financial distress yang mungkin dialami oleh perusahaan (Rahmayanti \& Hadromi, 2017). Berdasarkan hubungan teori signal dengan leverage menjelaskan bahwa manajemen dapat dikatakan mampu apabila dapat mengelola kekayaan perusahaan dengan baik dan mampu mempertahankan modal yang berasal dari hutang maupun modal sendiri menunjukkan bahwa, hal ini merupakan sinyal yang baik bagi pihak eksternal sehingga perusahaan tidak kehilangan kepercayaan kreditor untuk memberikan pinjaman dan investor. Semakin rendah tingkat leverage dapat menjadi sinyal yang baik kepada investor.

Hasil penelitian dari Agustina (2019), Lilis (2019), dan Dyah (2019) menunjukan bahwa leverage berpengaruh negatif dan signifikan terhadap financial distress. Namun berbeda dengan Apriliyandhika (2017), Indira (2018), Susilowati (2019), Susilowati, et.all (2019), dan Akhmad (2019) menunjukan bahwa leverage berpengaruh positif dan signifikan terhadap financial distress.

\section{Pengaruh Likuiditas Terhadap Financial Distress}

Likuiditas ialah kemampuan untuk melihat seberapa banyak perusahaan dalam membayarkan hutang jangka pendeknya yang segera harus dibayarkan (Dianova \& Nahumury, 2019). Berdasarkan hubungan teori signal dengan likuiditas menjelakan kepada pengguna laporan keuangan khususnya bagi pihak investor maupun kreditur terutama jika perusahaan berkualitas baik dapat menunjukkan sinyal yang baik, yang mana dapat menunjukkan sinyal positif berupa informasi yang relevan bagi pihak investor dan juga kreditur dikarenakan perusahaan telah dianggap mampu dalam melunasi hutang jangka lancarnya dan dianggap mampu untuk pengelolaannya. Apabila tingkat likuiditas dalam perusahaan tersebut tinggi maka dapat terhindar dari risiko terjadinya financial distress. Pada dasarnya investor juga melihat dari tingkat likuiditas dari suatu perusahaan apabila bernilai baik maka investor akan mendapat keyakinan penuh jika investasi yang dilakukannya pada perusahaan tersebut sudah tepat.

Pada penelitian yang dilakukan Susilowati (2019), Susilowati, et.all (2019), dan Saputri (2019) menunjukan bahwa likuiditas berpengaruh negatif signifikan terhadap financial distress. Namun berbeda dengan penelitian oleh Rahmayanti (2017) dan Dianova (2019) menunjukan bahwa likuiditas berpengaruh positif terhadap financial distress.

\section{Pengaruh Operating Capacity Terhadap Financial Distress}

Operating Capacity digunakan untuk melihat seberapa besar perusahaan mampu dalam mengatur kinerja keuangannya yang berupa asset perusahaan untuk kegiatan operasionalnya (Susilowati, et.all., 2019). Perputaran total aset tinggi menunjukan lebih besar efektivitas perusahaan pada waktu penggunaan asetnya guna menciptakan penjualan untuk menghasilkan keuntungan yang besar. Berdasarkan hubungan teori signal dengan operating capacity menjelaskan bahwa semakin meningkatnya perputaran aset perusahaan maka dapat menghasilkan hasil yang maksimal. Dalam hal ini, tingginya Total Asset Turn Over dapat menjadikan signal yang baik dari perusahaan bagi investor karena perusahaan telah mampu mendapatkan laba yang maksimal ketika rasio aktivitasnya tinggi. 
Hasil penelitian dari Aisyah dan Zultilisna (2017) dan Susilowati (2019) memperlihatkan bahwa operating capacity berpengaruh positif dan signifikan terhadap financial distress. Namun berbeda dengan penelitian Lisiantara (2018), Susilowati et.all (2019), dan Kartika (2019) menyatakan bahwa operating capacity berpengaruh negatif dan signifikan terhadap financial distress.

\section{Pengaruh Profitabilitas Terhadap Financial Distress}

Rasio profitabilitas ditunjukkan untuk melihat seberapa besar perusahaan mampu dalam memperoleh laba pada jangka waktu tertentu dengan cara memasarkan produk penjualannya, dengan demikian perusahaan dapat memperoleh laba yang diinginkannya yang merupakan salah satu penentu dari keberhasilan suatu perusahaan (Lisiantara \& Febrina, 2018). Berdasarkan hubungan teori signal dengan profitabilitas menunjukkan bahwa tingginya angka ROA akan menjadikan sinyal yang baik atau good news untuk pihak investor, dikarenakan menggambarkan kinerja keuangan perusahaan tersebut baik dari segi potensi keuangannya, dengan demikian semakin banyaknya investor yang akan tertarik menanamkan sahamnya kepada perusahaan, sehingga dapat mempengaruhi nilai investasi perusahaan yang akan naik. Dalam hal ini, semakin tingginya rasio ROA maka juga akan semakin meningkat laba yang telah dihasilkan perusahaan. (Susilowati \& Fadlillah, 2019).

Penelitian dari Aisyah dan Zultilisna (2017), Moch R (2019), dan Susilowati et.all (2019) menunjukkan bahwa profitabilitas berpengaruh negatif dan signifikan terhadap financial distress. Namun berbanding terbalik dengan penelitian yang dilakukan Saputri (2019), Zhafirah (2019) dan Fatimah (2019) menunjukan profitabilitas tidak berpengaruh signifikan terhadap financial distress.

\section{Pengaruh Sales Growth Terhadap Financial Distress}

Rasio sales growth digunakan untuk memprediksi pertumbuhan di tahun yang mendatang guna mencerminkan presentase dari keberhasilan investasi dimasa lalu (Dianova \& Nahumury, 2019). Peningkatan aset yang dimiliki oleh perusahaan dapat dilihat melalui pertumbuhan perusahaan. Jadi, apabila meningkatnya pertumbuhan penjualan maka dapat meningkatkan kemampuan perusahaan dalam memperoleh laba perusahaan dan jauh dari kata kesulitan keuangan. Dapat disimpulkan bahwa akan memberikan sinyal yang baik bagi investor ataupun kreditur dikarenakan sales growth yang baik dapat mempengaruhi aset dan laba perusahaan, dengan demikian baik dari investor maupun kreditur dapat tertarik untuk berinvestasi ke perusahaan. Sedangkan, jika sales growth menunjukkan angka yang kecil dalam hal ini dapat menyebabkan perusahaan berada dalam potensi adanya financial distress dikarenakan penjualan yang mengalami penurunan dari tahun sebelumnya hal ini berpengaruh terhadap asset, hutang dan laba perusahaan.

Penelitian dari Widhiari dan Merkusiwati (2015), Wulansari (2015), dan Amanda dan Tasman (2019) memperlihatkan bahwa sales growth berpengaruh negatif dan signifikan terhadap financial distress. Hal ini berbanding terbalik dengan penelitian Susilowati (2019) dan Dianova (2019) menunjukan bahwa sales growth tidak berpengaruh terhadap financial distress.

\section{Definisi Operasional dan Pengukuran Variabel Penelitian}

Penelitian dilakukan dengan variabel dependen financial distress dan menggunakan 6 variabel independen berupa arus kas operasi, leverage, likuiditas, operating capacity, profitabilitas dan sales growth.

\section{Arus Kas Operasi}

Menurut Ayuningtiyas \& Suryono (2019) rasio arus kas operasi menunjukkan keadaan keuangan suatu perusahaan yang menjadikan indikator bagi pihak investor dan juga kreditor. Untuk menghitung rasio arus kas operasi dengan rumus:

\section{Arus Kas Operasi $=\frac{\text { Arus Kas Operasi }}{\text { Total Asset }}$}

\section{Leverage}

Menurut Rahmayanti \& Hadromi (2017) pengukuran leverage dapat menggunakan debt to total asset ratio seperti dibawah ini:

DAR $=\frac{\text { Total Debt }}{\text { Total Asset }}$

\section{Likuiditas}

Menurut Dianova \& Nahumury (2019) rasio lancar untuk melihat seberapa banyak perusahaan mampu dalam melunasi hutang jangka pendeknya dengan membandingkan antara aset lancar dan kewajiban lancar untuk. Rasio likuiditas dapat diukur dengan menggunakan current asset sebagai berikut:

$\mathrm{CR}=\frac{\text { Current Asset }}{\text { Current Liabilities }}$

\section{Operating Capacity}

Menurut Yustika (2015) operating Capacity diukur menggunakan Total Asset Turnover. Operating capacity dapat dihitung dengan rumus sebagai berikut:

TATO $=\frac{\text { Sales }}{\text { Total Asset }}$

\section{Profitabilitas}

Menurut Lisiantara \& Febrina (2018) rasio profitabilitas diperuntukan dalam perusahaan guna mengukur 
seberapa besar keuntungan atau laba yang telah diperoleh perusahaan. Profitabilitas perusahaan diukur dengan:

$\mathrm{ROA}=\frac{\text { Earning After Tax }}{\text { Total Asset }}$

\section{Sales Growth}

Menurut Susilowati \& Fadlillah (2019) rasio sales growth yaitu untuk memperkirakan besar kecilnya suatu perusahaan untuk menjaga keadaan ekonominya apakah sudah sejalan dengan usahanya yang terus berkembang. Untuk menghitung sales growth dengan menggunakan rumus dibawah ini:

Sales Growth $=\frac{\text { Sales } t-\text { Sales } t-1}{\text { Sales } t-1}$

\section{Financial Distress}

Menurut Finishtya (2020) rasio yang digunakan untuk menghitung financial distress yaitu dengan menggunakan (ICR) Interest Coverage Ratio adalah rasio cakupan yang menggambarkan kemampuan peerusahaan dalam membayar bunganya. Financial Distress dapat dihitung dengan rumus sebagai berikut:

$I C R=\frac{\text { Earning Before Tax }}{\text { Interest Expense }}$

\section{METODE}

\section{Jenis Penelitian}

Jenis data dalam penelitian ini menggunakan data sekunder dengan jenis penelitian kuantitatif yang menggunakan data berupa angka-angka yang diperoleh dari perhitungan secara sistematis, yang sumber datanya diperoleh dari laporan keuangan dan laporan tahunan pada perusahaan Property dan Real Estate yang terdaftar di Bursa Efek Indonesia selama tahun 2015 - 2019.

\section{Populasi dan Sampel}

Populasi dalam penelitian ini dilakukan di perusahaan Property dan Real Estate yang telah terdaftar di Bursa Efek Indonesia dengan laporan keuangan dan laporan tahunan yang digunakan bersumber dari www.idx.co.id. Berdasarkan populasi yang diambil dengan kriteria-kriteria yang telah ditentukan mendapatkan 59 populasi yang terdaftar di Bursa Efek Indonesia.

Pada penelitian yang dilakukan dalam pemilihan metode sampel menggunakan metode purposive sampling. Berdasarkan metode purposive sampling kriteria yang telah ditetapkan pada penelitian ini ialah yang terdaftar di Bursa Efek Indonesia, laporan keuangan dan laporan tahunan yang mempunyai laba positif secara tetap. Terdapat 26 sampel perusahaan yang telah memenuhi kualifikasi pengambilan sampel dalam penelitian ini.

\section{HASIL DAN PEMBAHASAN}

Berdasarkan kualifikasi pengambilan sampel dalam penelitian ini diperoleh sampel dengan rincian tabel 1:

Tabel 1. Kualifikasi Pengambilan Sampel

\begin{tabular}{llc}
\hline \multicolumn{4}{c}{ Kriteria Sampel } & Jumlah \\
\hline 1 & $\begin{array}{l}\text { Perusahaan Property dan Real Estate } \\
\text { yang telah terdaftar di Bursa Efek }\end{array}$ & 59 \\
& $\begin{array}{l}\text { Indonesia (BEI) } \\
2\end{array}$ & $\begin{array}{l}\text { Perusahaan Property dan Real Estate di } \\
\text { BEI yang tidak melaporkan laporan } \\
\text { keuangan secara rutin periode 2015-2019 }\end{array}$ \\
\hline $3 \quad \begin{array}{l}\text { Perusahaan Property dan Real Estate di } \\
\text { BEI yang tidak dalam posisi laba berturut- }\end{array}$ & $(19)$ \\
turut selama periode 2015-2019 & $\mathbf{2 6}$ \\
\hline Jumlah Sampel Penelitian & $\mathbf{1 3 0}$
\end{tabular}

Sumber: Data sekunder yang dioalah, 2021

\section{Analisis Statistik Deskriptif}

Analisis statistik deskriptif menggambarankan suatu data yang dilihat dari nilai minimum dan maksimum data, rata - rata (mean), dan standar deviasi (Ghozali, 2018). Dibawah ini merupakan hasil dari analisis statistik deskriptif penelitian :

Tabel 2. Analisis Statistik Deskriptif

\begin{tabular}{lrrrrrrr} 
& \multicolumn{1}{c}{ FD } & \multicolumn{1}{c}{ CFO } & \multicolumn{1}{c}{ LEV } & LIK & OPCP & PROF & \multicolumn{1}{c}{ SG } \\
\hline N Valid & 130 & 130 & 130 & 130 & 130 & 130 & 130 \\
$\quad$ Missing & 0 & 0 & 0 & 0 & 0 & 0 & 0 \\
Minimum & 1,00 & 1,00 & 0,19 & 0,79 & 0,11 & 0,63 & 1,00 \\
Maxium & 3,31 & 1,55 & 0,99 & 3,13 & 0,62 & 2,93 & 1,87 \\
Mean & 1,9871 & 1,4414 & 0,5689 & 1,5015 & 0,4078 & 1,7837 & 1,6308 \\
Std. Deviation &, 60865 &, 05970 &, 18081 &, 52278 &, 12407 &, 61885 &, 13947 \\
\hline
\end{tabular}

Sumber: Hasil Data Penelitian, 2021

Berikut penjelasan dari tabel 2 di atas yang memperlihatkan hasil analisis statistik deskriptif :

1. Nilai rata-rata Arus Kas Operasi pengukuran yang digunakan dengan perbandingan arus kas operasi dengan total asset sebesar 1,4414. Hal ini diperoleh pada nilai rata-rata rasio Arus Kas Operasi pada perusahaan Property dan Real Estate di BEI selama tahun 2015-2019 sebesar 1,4414; nilai terendah sebesar 1,00 dan nilai tertinggi sebesar 1,55. Adapun nilai standar deviasi yang dihasilkan sebesar 0,0597. 
2. Nilai rata-rata Leverage dapat diukur menggunakan perbandingan hutang dengan total asset sebesar 0,5689. Hal ini diperoleh pada nilai rata-rata dari Leverage pada perusahaan Property and Real Estate di BEI selama tahun 2015-2019 sebesar 0,5689; nilai terendah sebesar 0,19 dan nilai tertinggi sebesar 0,99. Adapun nilai standar deviasi yang dihasilkan sebesar 0,18081 .

3. Nilai rata-rata Likuiditas diukur menggunakan perbandingan aktiva lancar dengan hutang lancar sebesar 1,5015. Hal ini diperoleh pada nilai rata-rata dari Likuiditas pada perusahaan Property dan Real Estate di BEI selama tahun 2015-2019 sebesar 1,5015; nilai terendah sebesar 0,79 dan nilai tertinggi sebesar 3,13. Adapun nilai standar deviasi yang dihasilkan sebesar 0,52278.

4. Nilai rata-rata Operating Capacity pengukuran yang digunakan dengan perbandingan penjualan dan total asset sebesar 0,4078. Hal ini diperoleh pada nilai rata-rata dari Operating Capacity pada perusahaan Property dan Real Estate di BEI selama tahun 20152019 sebesar 0,4078; nilai terendah sebesar 0,11 dan nilai tertinggi sebesar 0,62. Adapun nilai standar deviasi yang dihasilkan sebesar 0,12407.

5. Nilai rata-rata pada Profitabilitas pengukurannya menggunakan perbandingan laba bersih dengan total asset sebesar 1,7837. Hal ini diperoleh pada nilai rata-rata presentase laba bersih terhadap asset pada perusahaan Property dan Real Estate di BEI selama tahun 2015-2019 sebesar 1,7837; nilai terendah sebesar 0,63 dan nilai tertinggi sebesar 2,93. Adapun nilai standar deviasi yang dihasilkan sebesar 0,61885.

6. Nilai rata-rata pada Sales Growth diukur menggunakan perbandingan penjualan tahun berjalan dengan tahun berjalan dibandingkan dengan penjualan tahun sebelumnya sebesar 1,6308. Hal ini diperoleh pada nilai rata-rata Sales Growth pada perusahaan Property dan Real Estate di BEI selama tahun 2015-2019 sebesar 1,6308; nilai terendah sebesar 1,00 dan nilai tertinggi sebesar 1,87. Adapun nilai standar deviasi yang dihasilkan sebesar 0,13947.

7. Nilai rata-rata pada Financial Distress diukur menggunakan perbandingan EBIT (laba sebelum pajak) dibandingkan dengan biaya bunga sebesar 1,9871. Hal ini diperoleh pada nilai rata-rata Financial Distress pada perusahaan Property dan Real Estate di BEI selama tahun 2015-2019 sebesar 1,9871; nilai terendah sebesar 1,00 dan nilai tertinggi sebesar 3,31. Adapun nilai standar deviasi yang sebesar 0,60865.

\section{Uji Normalitas}

Tabel 3. Uji Normalitas

\begin{tabular}{|l|l|l|l|}
\hline $\begin{array}{l}\text { Kolmogorov- } \\
\text { Smirnov Z }\end{array}$ & Asymp.Sig. & Standar & Keputusan \\
\hline 1,356 & 0,200 & $>0,05$ & Normal \\
\hline
\end{tabular}

Sumber: Hasil Data Penelitian, 2021
Tabel 3 di atas menunjukkan hasil uji normalitas, diketahui bahwa nilai Asymp.Sig. (2-Tailed) sebesar $0,200>\alpha(0,05)$. Berdasarkan hal tersebut, telah memenuhi uji asumsi normalitas dan menunjukkan bahwa nilai residual dari data berdistribusi normal.

\section{Uji Multikolenieritas}

Tabel 4. Uji Multikolenieritas

\begin{tabular}{lccc}
\hline Variabel & Tolerance & VIF & Kesimpulan \\
\hline CFO &, 462 & 2,163 & Tidak terjadi \\
LEV &, 538 & 1,859 & Tidak terjadi \\
LIK &, 444 & 2,253 & Tidak terjadi \\
OPCP &, 467 & 2,142 & Tidak terjadi \\
PROF &, 626 & 1,597 & Tidak terjadi \\
SG &, 296 & 3,373 & Tidak terjadi \\
\hline
\end{tabular}

Sumber: Hasil Data Penelitian, 2021

Pada tabel 4 di atas, variabel independen pada nilai tolerance tidak ada yang kurang dari 0,10 . Pada variabel arus kas operasi nilai tolerance sebesar 0,462 > 0,10 ; variabel leverage nilai tolerance sebesar $0,538>$ 0,10 ; variabel likuiditas nilai tolerance sebesar $0,444>$ 0,10 ; variabel operating capacity nilai tolerance sebesar 0,467 ; variabel profitabilitas nilai tolerance sebesar $0,467>0,10$; dan variabel sales growth nilai tolerance sebesar $0,296>0,10$.

Hal ini juga ada dalam angka VIF nilainya yaitu < 10 untuk VIF variabel arus kas operasi sebesar 2,163 < 10; VIF untuk variabel leverage sebesar $1,859<10$; VIF untuk variabel likuiditas sebesar $2,253<10$; VIF variabel operating capacity sebesar 1,683 < 10; VIF variabel profitabilitas sebesar $1,570<10$ dan VIF variabel sales growth sebesar 3,593 < 10. Dalam hal ini, data-data penelitian tidak terdapat gangguan multikolinearitas dalam model regresi dikarenakan $<10$.

\section{Uji Heterokedastisitas}

Tabel 5. Uji Heterokedastisitas

\begin{tabular}{llll}
\hline \multicolumn{1}{c}{ Variabel } & Sig & Standar & Kesimpulan \\
\hline CFO &, 757 & $>0,05$ & Tidak terjadi \\
LEV &, 676 & $>0,05$ & Tidak terjadi \\
LIK &, 964 & $>0,05$ & Tidak terjadi \\
OPCP &, 874 & $>0,05$ & Tidak terjadi \\
PROF &, 102 & $>0,05$ & Tidak terjadi \\
SG &, 210 & $>0,05$ & Tidak terjadi \\
\hline
\end{tabular}

Sumber: Hasil Data Penelitian, 2021

Berdasarkan dari tabel 5 di atas, menunjukkan probabilitas signifikansi diatas $5 \%$ atau 0,05 pada masing-masing variabel. Maka dalam model regresi dari penelitian ini, tidak terjadi adanya heteroskedastisitas.

\section{Uji Autokorelasi}


Tabel 6. Uji Autokorelasi

\begin{tabular}{cccccc}
\hline Model & $\mathrm{R}$ & $\mathrm{R}^{2}$ & $\operatorname{Adj~R}^{2}$ & $\begin{array}{c}\text { Std. Error } \\
\text { of the } \\
\text { Estimate }\end{array}$ & $\begin{array}{c}\text { Durbin- } \\
\text { Watson }\end{array}$ \\
\hline 1 &, $675^{\mathrm{a}}$ &, 456 &, 429 &, 45983 & 1,700
\end{tabular}

Sumber: Hasil Data Penelitian, 2021

Berdasarkan tabel 6 menunjukkan hasil uji autokorelasi, dengan nilai DW hitung sebesar 1,700. Berdasarkan kriteria pengambilan keputusan diketahui bahwa nilai dU $(1,6184)<\mathrm{DW}(1,700)<4-\mathrm{dU}$ $(2,3816)$, sehingga dinyatakan tidak terdapat autokorelasi pada data tersebut. Dikarenakan angka $D W$ test terdapat diantara (du tabel) dan (4-du tabel), dengan demikian pada model regresi dari uji autokorelasi tersebut dinyatakan layak untuk dipakai.

\section{Uji F}

Tabel 7. Uji F

\begin{tabular}{lrrrrr}
\hline Model & $\begin{array}{r}\text { Sum of } \\
\text { Squares }\end{array}$ & df & $\begin{array}{l}\text { Mean } \\
\text { Square }\end{array}$ & F & Sig. \\
\hline Regression & 21,780 & 6 & 3,630 & 17,168 &, $000^{\mathrm{a}}$ \\
Residual & 26,008 & 123 &, 211 & & \\
Total & 47,778 & 129 & & & \\
\hline
\end{tabular}

Sumber: Hasil Data Penelitian, 2021

Berdasarkan tabel 7 menunjukkan hasil uji $\mathrm{F}$, memiliki nilai signifikansi sebesar $(0,000)<$ taraf signifikan $\alpha(0,05)$. Diperoleh hasil secara simultan dari variabel arus kas operasi, leverage, likuiditas, operating capacity, profitabilitas dan sales growth memiliki pengaruh yang signifikan dalam memprediksi financial distress.

\section{Uji Koefisien Determinasi (Adjusted $\mathbf{R}^{2}$ )}

Tabel 8. Uji Koefisien Determinasi $\left(\mathrm{R}^{2}\right)$

\begin{tabular}{lcrrr}
\hline Model & $\mathrm{R}$ & $\begin{array}{c}\mathrm{R} \\
\text { Square }\end{array}$ & $\begin{array}{l}\text { Adjusted } \\
\text { R Square }\end{array}$ & $\begin{array}{l}\text { Std. Error of } \\
\text { the Estimate }\end{array}$ \\
\hline 1 & $675^{\mathrm{a}}$ &, 456 &, 429 &, 45983
\end{tabular}

Sumber: Hasil Data Penelitian, 2021

Berdasarkan output dari tabel 8 di atas, diperoleh nilai koefisien determinasi ( $R$ Square) sebesar 0,456 yang mana menunjukkan besarnya persentase pengaruh variabel arus kas operasi, leverage, likuiditas, operating capacity, profitabilitas dan sales growth terhadap variabel terikatnya yaitu financial distress adalah sebesar $45,6 \%$. Sedangkan sebanyak $54,4 \%$ sebagian besar telah dipengaruhi oleh variabel selain dari penelitian ini.

\section{Hasil Uji Hipotesis \\ Analisis Regresi Berganda}

Pada uji penelitian ini berperan untuk melihat sejauh mana pengaruh arus kas operasi, likuiditas, leverage, operating capacity, profitabilitas, dan sales growth dalam memprediksi adanya financial distress periode 2015-2019 pada perusahaan Property dan Real Estate yang terdaftar di BEI. Dibawah ini merupakah hasil dari uji persamaan regresi:

Tabel 9. Hasil Uji Hipotesis

\begin{tabular}{|c|c|c|c|c|c|}
\hline \multirow[b]{2}{*}{ Model } & \multicolumn{2}{|c|}{ Unstandardized Coefficients } & Standardized Coefficients & \multirow[b]{2}{*}{$\mathrm{T}$} & \multirow[b]{2}{*}{ Sig. } \\
\hline & B & Std. Error & Beta & & \\
\hline (Constant) & 3,946 & 1.427 & & 2.766 & ,007 \\
\hline $\mathrm{CFO}$ & $-1,231$ & 997 &,- 121 & -1.234 & 220 \\
\hline LEV & $-1,576$ & ,305 &,- 468 & -5.163 & 000 \\
\hline LIK & $-0,267$ & 116 &,- 229 & -2.295 & 023 \\
\hline OPCP & $-0,249$ & ,478 &,- 051 &,- 522 & 603 \\
\hline PROF & 0,002 & 083 &, 002 & 021 & 984 \\
\hline SG & 0,742 & ,533 & ,170 & 1.392 & ,166 \\
\hline
\end{tabular}

Sumber: Hasil Data Penelitian, 2021

Berikut adalah persamaan regresi pada tabel 9 diatas :

$\mathrm{FD}=3,946-1,231 \mathrm{CFO}-1,576 \mathrm{LEV}-0,267 \mathrm{LIK}-$ $0,249 \mathrm{OPCP}+0,002 \mathrm{PROF}+0,742 \mathrm{SG}+\varepsilon$

\section{Uji Hipotesis (Uji Statistik t)}

Uji hipotesis (Statistik t) bertujuan dalam mengungkapkan pengaruh antara variabel independen dengan variabel dependen (Ghozali, 2018). Dengan melihat tingkat signifikansi 0,05 atau $5 \%$. Berdasarkan hasil uji statistik t menyatakan adanya pengaruh variabel independen terhadap variabel dependen. Berikut merupakan penjelasan mengenai hasil uji statistik t:
1. Pengaruh Arus Kas Operasi terhadap Financial Distress

Berdasarkan tabel 9 diperoleh hasil variabel dari arus kas operasi secara parsial, tidak ada pengaruh yang signifikan terhadap financial distress sehingga hipotesis ke tiga $\left(\mathrm{H}_{1}\right)$ ditolak. Mengindikasikan bahwa tinggi rendahnya arus kas operasi tidak bisa menjelaskan dan meningkatkan financial distress. Sebab, arus kas mempunyai sumber informasi yang saling berhubungan dan saling tergantung antar aktivitas yang ada dalam arus kas. Pada laporan arus kas terdiri dari kegiatan operasi, investasi dan pendanaan. Pada dasarnya, laporan arus kas terdapat aktivitas operasi yang hanya memberikan keterangan tentang kegiatan operasional 
yang dilakukan perusahaan. Apabila dari hasil penerimaan penjualan menunjukkan beban operasi lebih besar dari yang dikeluarkan mengidentifikasikan bahwa nilai arus kas dari operasi tersebut tinggi. Hasil penelitian ini juga sejalan dengan Carolina dan Pratama (2017), Finishtya (2020), Purnamawati (2019), dan Ayuningtyas (2019) membuktikan bahwa arus kas operasi tidak berpengaruh signifikan terhadap financial distress.

2. Pengaruh Leverage terhadap Financial Distress

Berdasarkan tabel 9 menunjukkan leverage secara parsial, ada pengaruh yang signifikan dan negatif terhadap financial distress sehingga hipotesis ke dua $\left(\mathrm{H}_{2}\right)$ diterima. Dalam hal ini, leverage memiliki pengaruh negatif terhadap financial distress dikarenakan walaupun perusahaan mempunyai banyak hutang tetapi perusahaan masih mampu melunasi hutang dan bunga dari hutang tersebut. Menununjukkan bahwa meskipun perusahaan memiliki jumlah hutang yang besar, perusahaan tetap memiliki kinerja yang baik. Jadi apabila tingkat kewajiban hutangnya tinggi, keadaan yang mengarah pada financial distress justru dapat berkurang sebab perusahaan masih dikatakan mampu dalam membayarkan bunga perusahaan. Tetapi apabila tidak segera diatasi maka dapat terjadi adanya financial distress. Hasil penelitian juga sejalan dengan Dianova (2019) dan Saputri (2019) menunjukan bahwa leverage berpengaruh negatif dan signifikan terhadap financial distress.

3. Pengaruh Likuiditas terhadap Financial Distress

Berdasarkan tabel 9 menunjukkan likuiditas secara parsial, ada pengaruh yang signifikan terhadap financial distress sehingga hipotesis ke tiga $\left(\mathrm{H}_{3}\right)$ diterima. Mengindikasikan bahwa meningkatnya likuiditas suatu perusahaan dapat terhindar dari adanya financial distress. Apabila meningkatnya likuiditas maka berpengaruh kemampuan perusahaan dalam membayarkan kewajiban jangka pendeknya dapat semakin baik. Dikarenakan jumlah asset lancar lebih besar dari jumlah hutang lancarnya. Dengan demikian, celah yang memungkinkan perusahaan mengarah pada potensi financial distress itu kecil karena perusahaan dikatakan mampu mengelola asset lancarnya dalam pembayaran hutang jangka pendeknya. Hasil penelitian ini juga sejalan dengan Susilowati (2019), Susilowati et.all (2019), dan Saputri (2019) menunjukan bahwa likuiditas berpengaruh negatif signifikan terhadap financial distress.

4. Pengaruh Operating Capacity terhadap Financial Distress

Berdasarkan tabel 9 diperoleh hasil variabel menunjukkan operating capacity secara parsial, tidak ada pengaruh yang signifikan terhadap financial distress sehingga hipotesis ke empat $\left(\mathrm{H}_{4}\right)$ ditolak. Mengindikasikan bahwa apabila semakin tinggi atau rendahnya operating capacity tidak dapat mempengaruhi financial distress. Maka perusahaan tersebut dalam kondisi tidak baik dan mengalami potensi adanya financial distress. Dimana hasil penelitian yang telah dilakukan tidak mendukung teori signal dimana teori tersebut menerangkan mengenai tindakan-tindakan apa saja yang dapat diambil oleh manajemen perusahaan guna mendapatkan informasi yang relevan bagi investor maupun kreditur mengenai keadaan yang sedang dilalukan perusahaan. Hasil penelitian ini sejalan dengan Apriliyandhika (2017) menyatakan bahwa operating capacity tidak berpengaruh signifikan terhadap financial distress.

5. Pengaruh Profitabilitas terhadap Financial Distress

Berdasarkan tabel 9 menunjukkan profitabilitas secara parsial, tidak ada pengaruh yang signifikan terhadap financial distress sehingga hipotesis ke lima $\left(\mathrm{H}_{5}\right)$ ditolak. Mengindikasikan bahwa meningkat atau menurunnya profitabilitas tidak dapat meningkatkan financial distress. Pada dasarnya, tidak sesuai dengan teori signal yang menunjukkan bahwa tingginya profitabilitas dapat memberikan sinyal yang positif bagi pihak investor. Hasil penelitian ini juga sejalan dengan Saputri (2019), Zhafirah (2019) dan Fatimah (2019) menunjukan profitabilitas tidak berpengaruh signifikan terhadap financial distress.

6. Pengaruh Sales Growth terhadap Financial Distress

Berdasarkan tabel 9 diperoleh hasil dari variabel sales growth secara parsial, tidak ada pengaruh yang signifikan terhadap financial distress sehingga hipotesis ke enam $\left(\mathrm{H}_{6}\right)$ ditolak. Memperlihatkan bahwa apabila penjualan perusahaan tersebut tinggi, memungkinkan perusahaan tersebut dapat terbebas dari adanya financial distress. Namun, jika dari penjualan masih menemui penurunan maka dapat dikatakan perusahaan kurang baik dan dapat dikatakan mengalami financial distress. Pada dasarnya, sales growth dalam memberikan informasi kepada investor belum mampu menyampaikan secara akurat. Hasil penelitian ini sejalan dengan Susilowati (2019), Lisiantara (2018) dan Dianova (2019) menunjukan bahwa sales growth tidak berpengaruh terhadap financial distress.

\section{SIMPULAN}

Penelitian ini bertujuan untuk mengetahui pengaruh faktor - faktor yang mempengaruhi financial distress. Populasi yang digunakan sektor Pperusahaan Property dan Real Estate yang terdaftar di BEI tahun 2015-2019. Terdapat 26 sampel perusahaan yang memenuhi kualifikasi kriteria, sehingga diperoleh 130 observasi dari periode 2015-2019. Metode pengujian data melalui analisis regresi linier berganda dapat disimpulkan pada pengujian kelayakan model (uji F) menunjukkan variabel arus kas operasi, leverage, likuiditas, operating capacity, profitabilitas, dan sales growth berpengaruh secara bersamaan terhadap financial distress. Namun dalam pengujian hipotesis (uji-t) 
variabel arus kas operasi, operating capacity, profitabilitas dan sales growth tidak berpengaruh terhadap financial distress, sedangkan variabel leverage dan likuiditas berpengaruh signifikan dan negatif terhadap financial distress.

\section{DAFTAR PUSTAKA}

Aisyah, N. N., Kristanti, F. T., \& Zultilisna, D. (2017). Pengaruh Rasio Likuiditas, Rasio Aktivitas, Rasio Profitabiltas, dan Rasio Leverage Terhadap Financial Distress (Studi pada Perusahaan Tekstil Dan Garmen yang terdaftar di Bursa Efek Indonesia Tahun 2011-2015. e-Proceeding of Management, 4(1), 411-419.

Amanda, Y., \& Tasman, A. (2019). Pengaruh Likuiditas, Leverage, Sales Growth dan Ukuran Perusahaan Terhadap Financial Distress Pada Perusahaan Manufaktur yang Terdaftar di Bursa Efek Indonesia (BEI) Periode 2015-2017. Analisis Prokrastinasi dalam Mengerjakan Skripsi pada Mahasiswa Jurusan Pendidikan Ekonomi Angkatan 2015, Universitas Negeri Padang, 2(3), 453-462.

Ayuningtiyas, I. S., \& Suryono, B. (2019). Pengaruh Likuiditas, Profitabilitas, Leverage Dan Arus Kas Terhadap Kondisi Financial Distress. Jurnal Ilmu dan Riset Akuntansi, 8(1), 1-16.

Carolina, V., Marpaung, E. I., \& Pratama, D. (2017). Analisis Rasio Keuangan untuk Memprediksi Kondisi Financial Distress (Studi Empiris pada Perusahaan Manufaktur yang Terdaftar di Bursa Efek Indonesia Periode 2014-2015). Jurnal Akuntansi Maranatha, 9(2), 137-145.

Dianova, A., \& Nahumury, J. (2019). Investigating The Effect Of Liquidity, Leverage, Sales Growth And Good Corporate Governance On Financial Distress. Journal of Accounting and Strategic Finance, 2(2), 143-156.

Fatimah, Toha, A., \& Prakoso, A. (2019). The Influence of Liquidity, Leverage and Profitability Ratio on Financial Distress (On Real Estate and Property Companies Listed in Indonesia Stock Exchange in 2015-2017). RISET \& JURNAL AKUNTANSI, 3(1), 103-115.

Febriyan, \& Prasetyo, A. H. (2019). Pengaruh Arus Kas Operasi, Likuiditas, Leverage, Diversifikasi Dan Ukuran Perusahaan Terhadap Financial Distress (Studi empiris pada perusahaan sektor aneka industri yang terdaftar di BEI 2014-2016). Jurnal Akuntansi, 8(1), 103-116.

Febriyanto , F. C. (2018). The Effect Of Leverage, Sales Growth And Liquidity To The Firm Value Of Real Estate And Property Sector In Indonesia Stock Exchange. Economics and Accounting Journal, 1(3), 198-205.

Finishtya, F. C. (2020). Apakah Profitabilitas, Ukuran Perusahaan Dan Arus Kas Operasi Dapat Memprediksi Financial Distress Perusahaan
((Studi Empiris Pada Perusahaan Sektor Industri Barang dan Konsumsi 2015-2017). Jurnal Riset Akuntansi, 10(1), 11-21.

Ghozali, I. (2018). Aplikasi Analisis Multivariate Dengan Program IBM SPSS 25 (9 ed.). Semarang: Badan Penerbit Universitas Dipenogoro.

Julius, F. (2017). Pengaruh Finacial Leverage, Firm Growth,Laba dan Arus Kas Terhadap Financial Distress (Studi Empiris pada Perusahaan Manufaktur yang Terdaftar). JOM Fekon, 4(1), 1164-1178.

Kanzha, D. D., \& Muslih, M. (2020). Pengaruh Arus Kas Operasi, Leverage Dan Firm Growth Terhadap Financial Distress (Studi Pada Perusahaan Pertanian yang Terdaftar di Bursa Efek Indonesia). e-Proceeding of Management, $7(2), 2669-2676$.

Kartika, R., \& Hasanudin. (2019). Analisis Pengaruh Likuiditas, Leverage, Aktivitas, dan Profitabilitas Terhadap Financial Distress Pada Perusahaan Terbuka Sektor Infrastruktur, Utilitas, dan Transportasi Periode 2011-2015. Jurnal Ilmu Manajemen, 15(1), 1-16.

Lisiantara, G. A., \& Febrina, L. (2018). Likuiditas, Leverage, Operating Capacity, Profitabilitas, Sales Growth Sebagai Preditor Financial Distress (Studi Empiris Pada Perusahaan Manufaktur Yang Terdaftar Di Bursa Efek Indonesia Tahun 20132016. Jurnal Prosiding SENDI_U, 764-772.

Moch, R., Prihatni, R., \& Buchdadi, D. A. (2019). The Effect Of Liquidity, Profitability And Solvability To The Financial Distress Of Manufactured Comanies Listed On The Indonesia Stock Exchange (IDX) Period Of Year 2015-2017. Academy of Accounting and Financial Studies Journal, 23(6), 1-16.

Moch, R., Prihatni, R., \& Buchdadi, D. A. (2019). The Effect Of Liquidity, Profitability And Solvability To The Financial Distress Of Manufactured Companies Listed On The Indonesia Stock Exchange (IDX) Period Of Year 2015-2017. Academy of Accounting and Financial Studies Journal, 23(6), 1-16.

Nukmaningtyas, F., \& Worokinasih, S. (2018). Penggunaan Rasio Profitabilitas, Likuiditas, Leverage dan Arus Kas Untuk Memprediksi Financial Distress (Studi Pada Perusahaan Sektor Aneka Industri Yang Terdaftar Di Bursa Efek Indonesia Periode 2013 - 2016). Jurnal Administrasi Bisnis, 60(1), 136-143.

Rahmayanti, S., \& Hadromi, U. (2017). Analisis Financial Distress Pada Perusahaan Manufaktur Yang Terdaftar di Bursa Efek Indonesia. Jurnal Akuntansi dan Ekonomika, 7(1), 53-63.

Ramadhani, A. L., \& Khairunnisa. (2019). Pengaruh Operating Capacity, Sales Growth Dan Arus Kas Operasi Terhadap Financial Distress (Studi Empiris pada Perusahaan Sektor Pertanian yang 
Terdaftar di Bursa Efek Indonesia Periode 20132017). Jurnal Riset Keuangan Dan Akuntansi, 5(1), 75-82.

Restianti, T., \& Agustina, L. (2018). The Effect of Financial Ratios on Financial Distress Conditions in Sub Industrial Sector Company. Accounting Analysis Journal, 7(1), 25-33.

Saputri, L., \& Asrori. (2019). The Effect of Leverage, Liquidity and Profitability on Financial Distress with the Effectiveness of the Audit Committee as a Moderating Variable. Accounting Analysis Journal, 8(1), 38-44.

Susilowati, P. I., \& Fadlillah, M. R. (2019). FaktorFaktor Yang Mempengaruhi Financial Distress Pada Perusahaan Manufaktur Di Indonesia. Jurnal AKSI (Akuntansi dan Sistem Informasi), 4(1), 1928.

Susilowati, Y., Suwarti, T., Puspitasari, E., \& Nurmaliani, A. F. (2019). The Effect Of Liquidity, Leverage, Profitability, Operating Capacity, And Managerial Agency Cost On Financial Distress Of Manufacturing Companies Listed In Indonesian Stock Exchange. Advances in Economics, Business and Management Research, 100, 651656.

Widhiari, N. M., \& Merkusiwati, N. A. (2015). Pengaruh Rasio Likuiditas, Leverage, Operating Capacity Dan Sales Growth Terhadap Financial Distress. EJurnal Akuntansi Universitas Udayana, 11(2), 456-469.

Wulansari, A. P. (2015). Pengaruh Aktivitas, Leverage dan Pertumbuhan Perusahaan Dalam Memprediksi Financial Distress (Studi Empiris Perusahaan Manufaktur Yang Terdaftar Di BEI Tahun 20132015). Jurnal Ilmiah Riset Akuntansi, 6(4), 136146.

Yustika, Y. (2015). Pengaruh Likuiditas, Leverage, Profitabilitas, Operating Capacity Dan Biaya Agensi Manajerial Terhadap Financial Distress (Studi Empiris pada Perusahaan Manufaktur yang Terdaftar). Doctoral Dissertation, Riau University, 2(2), 1-15.

Zhafirah, A., \& Majidah. (2019). Analisis Determinan Financial Distress (Studi Empiris Pada Perusahaan Subsektor Tekstil dan Garmen Periode 20132017). Jurnal Riset Akuntansi dan Keuangan, 7(1), 195-202. 